\title{
The Scandinavian Container at San Isidoro, León, in the Context of Viking Art and Society
}

\author{
Nancy L. Wicker
}

\begin{abstract}
A cylindrical container at San Isidoro in León is the only Viking object known from the Iberian Peninsula. Here the León piece is compared to other Viking artifacts of similar style and similar materials to place it in its context. The cylinder most probably is red-deer antler, and the carving is executed in the late-tenth and early-eleventh-century Viking style called Mammen. The motif on the box is a bird of prey with splayed-out wings and with its head carved three dimensionally looking downward from the top of the cylinder like a gargoyle. The antler body of the object as well as the metal top and bottom are pierced, suggesting that the function of the box may have been to hold aromatic scents. Although Vikings harried the coast of the Iberian Peninsula from the mid-ninth through the twelfth centuries, it is not likely that the piece was a casual loss by a hostile invader. More likely, it was a marriage gift associated with a northern woman who came to Iberia as a bride, a hybrid object made to order for someone who could appreciate the Viking animal style of the ornamentation combined with the exotic use of aromatics unknown in the north.
\end{abstract}

\section{Keywords}

gifts - hybridization - Iberia - ivory - Vikings - women

\section{1 \\ Introduction}

A 4.4-cm-high perforated cylindrical container sits among reliquaries of diverse geographic origins in the treasury of the collegiate church of San Isidoro in León, Spain (Figure 9.1). This now empty box differs from the other reliquaries in the collection since its style is recognizably Scandinavian. In fact, it is the only attested Viking object discovered in the Iberian Peninsula. ${ }^{1}$ The piece

1 Else Roesdahl, "From Scandinavia to Spain: A Viking-Age Reliquary in León and Its Meaning," in The Viking Age: Ireland and the West. Proceedings of the Fifteenth Viking Congress, ed. John Sheehan and Donnchadh Ó Corráin (Dublin: Four Courts Press, 2010), 353-36o, esp. 353. 
has been discussed several times by Danish archaeologist Else Roesdahl and is the subject of a recent master's thesis at the University of Oslo by Rebeca Franco Valle. ${ }^{2}$ To place the box in its context, I will review the work done by these scholars and others - as well as bring attention to certain details-as I compare the León box to other Viking artifacts made of related materials and of similar style and form. Finally, I will propose how the object could have reached San Isidoro and how it may have been used.

Before examining the León piece in detail, let us consider how it has been described since it was first published in $1925^{-26}$ by Manuel Gómez-Moreno as a little ivory box in reference to the San Isidoro treasury. ${ }^{3}$ Some authors simply call it a small cylinder. ${ }^{4}$ Others refer to it as a casket, which means a small chest or box, often a rectangular container for either jewelry or Christian relics. We have no evidence that the cylindrical León object was originally made for either of these purposes, only Gómez-Moreno's brief note that mentions it might hold relics - presumably physical remains or personal effects of a saint or venerated person. Adolph Goldschmidt turns Gómez-Moreno's conditional statement into an assertion that the box held a relic. ${ }^{5}$ Subsequently, both Signe Horn Fuglesang and Roesdahl designate the León box a reliquary casket. ${ }^{6}$ The eventual use of the piece at San Isidoro may have been as a container for relics, yet it is unlikely that this Viking-style work was intended for that purpose. Christian use of the item has apparently been assumed because it was housed in a church. If it were used to house relics such as bones, the fragments may have been either larger than the perforations in the box or wrapped in cloth

2 Else Roesdahl, "Cammin—Bamberg—Prague—Léon [sic]: Four Scandinavian Objects d'Art in Europe," in Studien zur Archäologie des Ostseeraumes. Von der Eisenzeit zum Mittelalter. Festschrift für Michael Müller-Wille, ed. Anke Wesse (Neumünster: Wachholtz Verlag, 1998), 547-554; Roesdahl, "From Scandinavia to Spain;" Roesdahl, "Viking Art in European Churches (Cammin-Bamberg_-Prague-León)” in Viking Trade and Settlement in Continental Western Europe, ed. Iben Skibsted Klæsøe (Copenhagen: Museum Tusculanum, University of Copenhagen Press, 2010), 149-164; and Rebeca Franco Valle, "Viking Art in the Church: A Scandinavian Casket in San Isidoro de León, Spain," unpublished MPhil thesis, University of Oslo, 2016.

3 Manuel Gómez-Moreno, Catálogo monumental de España: Provincia de León (19o6-19o8), 2 vols. (Madrid: Ministerio de Instrucción Pública y Bellas Artes, 1925-26), 1:195.

4 Jan Skamby Madsen, The Danish Vikings (Copenhagen: Royal Danish Ministry of Foreign Affairs, 1992), 19 .

5 Adolph Goldschmidt, Die Elfenbeinskulpturen aus der romanischen Zeit XI.-XIII.Jahrhundert. Die Elfenbeinskulpturen, 4 (Berlin: Verlag Bruno Cassirer, 1926. Reprint, Berlin: Deutscher Verlag für Kunstwissenschaft, 1975), 57 .

6 Signe Horn Fuglesang, "Animal Ornament: The Late Viking Period," in Tiere, Menschen, Götter: Wikingerzeitliche Kunststile und ihre neuzeitliche Rezeption, ed. Michael Müller-Wille and Lars Olof Larsson. Veröffentlichung Joachim Jungius-Gesellschaft der Wissenschaften Hamburg, 9o (Göttingen: Vandenhoeck \& Ruprecht, 2001), 157-194; and Roesdahl, "From Scandinavia to Spain," where the term reliquary appears in the title of her essay. 


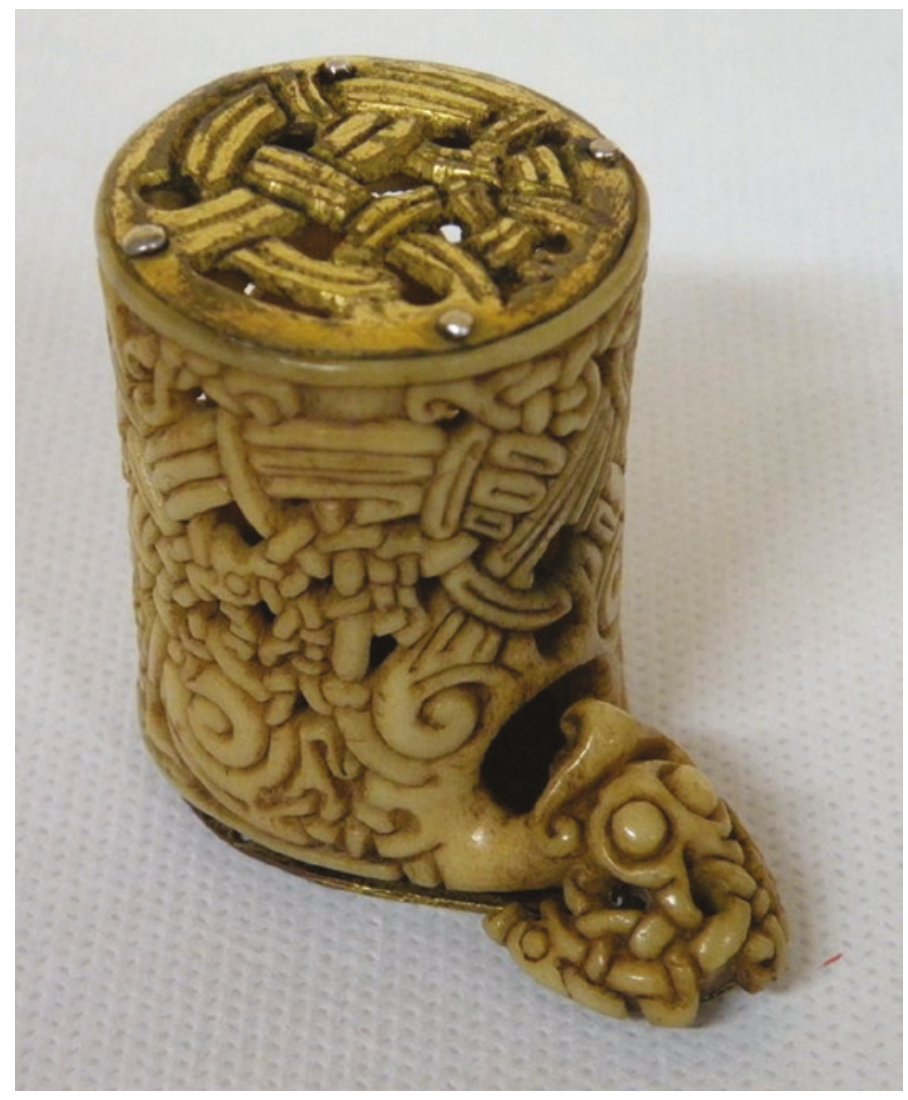

FIGURE 9.1 León cylinder (upside-down). Red deer antler and gilt copper alloy, $4.4 \mathrm{~cm}$. (Museo de la Real Colegiata de San Isidoro de León, Inv. No. IIC-3-089-ooz-ooog). See also Figs. 2.1a, 2.1b.

PHOTO: THERESE MARTIN

before being placed inside the container. ${ }^{7}$ Roesdahl suggests that instead of containing relics, the León piece may have been a Christian pyx to hold the

7 Wrapping relics has been addressed recently by Martina Bagnoli, "Dressing the Relics: Some Thoughts on the Custom of Relic Wrapping in Medieval Christianity" in Matter of Faith: An Interdisciplinary Study of Relics and Relic Veneration in the Medieval Period, ed. James Robinson and Lloyd de Beer (London: British Museum, 2014), 100-109; Visa Immonen and JussiPekka Taavitsainen, "Finger of a Saint, Thumb of a Priest: Medieval Relics in the Diocese of Turku, and the Archaeology of Lived Bodies," in Religion and the Body: Based on Papers Read at the Symposium on Religion and the Body Held at Åbo, Finland on 16-18 June 2010, ed. Tore Ahlbäck, Scripta Instituti Donneriani Aboensis, 23 (Turku: Donner Institute, 2011), 141-173; and Massimo Leone, "Wrapping Transcendence: The Semiotics of Reliquaries," Signs and Society $2 / \mathrm{S}_{1}(2014): \mathrm{S}_{49}-\mathrm{S}_{3}$. 


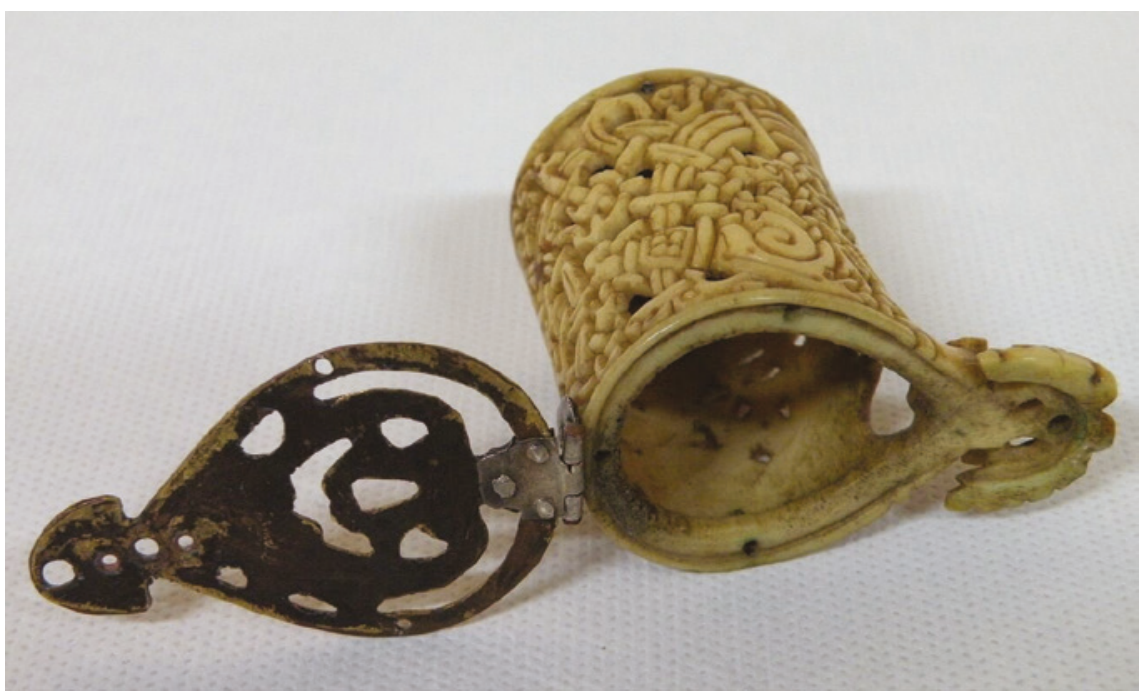

FIGURE 9.2 León cylinder. View into interior with projecting tine at right. Red deer antler and gilt copper alloy, $4.4 \mathrm{~cm}$. (Museo de la Real Colegiata de San Isidoro de León, Inv. No. IIC-3-089-002-0oo9). See also Figs. 2.1a, 2.1b. PHOTO: THERESE MARTIN

consecrated host, and Danielle Gaborit-Chopin also lists it as a pyxis without specifying whether she intends the classical meaning as any small cylindrical box with a lid or the explicitly Christian use of a pyx. ${ }^{8}$ Wendy Davies calls the piece the León idol, but there is no reason to believe that a small box would be considered an idol by Vikings or anyone else. ${ }^{9}$ I prefer to describe the piece in a neutral way as a cylinder or a box.

The material of the box has been referred to as various osseous materials: ivory, walrus ivory, bone, whalebone, and antler (of both red deer and reindeer),

8 Roesdahl, "Cammin—Bamberg—Prague—Léon [sic]," 553; Danielle Gaborit-Chopin, Elfenbeinkunst im Mittelalter, trans. Gisela Bloch and Roswitha Beyer (first ed., Ivoires du Moyen Âge [Fribourg, Switz.: Office du Livre, 1978], Berlin: Gebr. Mann, 1978), 195, no. 84. Therese Martin, in a personal e-mail message to the author of 7 August 2018, noted that the León piece is too small to be used as a pyx.

9 Wendy Davies, "Treasure-A View from the South," in Early Medieval Art and Archaeology in the Northern World: Studies in Honour of James Graham-Campbell, ed. Andrew Reynolds and Leslie Webster (Leiden: Brill, 2013), 540-557, esp. 541. 
and it has also been compared to objects made of horn. In his 1925 discussion of the treasury of San Isidoro, Gómez-Moreno referred to the León box as ivory. ${ }^{10}$ Ivory normally denotes elephant ivory unless another specific animal from which it derives is identified. In medieval Europe, elephant ivory was scarce, and walrus ivory obtained from Scandinavia, especially Iceland and Greenland, was also used." In the 1993 catalogue of the exhibition The Art of Medieval Spain, A.D. 500-1200 at the Metropolitan Museum of Art, Charles T. Little lists the material as walrus ivory, as does Gaborit-Chopin in her catalogue of medieval ivories. ${ }^{12}$ Although Gómez-Moreno and his followers assumed the León piece was made of ivory, Goldschmidt in his 1926 catalogue of ivories and similar materials listed the León box as bone. ${ }^{13}$ Through the years, many scholars have depended upon his appraisal. Fuglesang, a Norwegian art historian of the Viking Age, specifies that the material is whalebone, an assertion that is repeated by Ann Christys in 2015. ${ }^{14}$ Ivory is dentine material - teeth or tusks - covered with a smooth enamel layer, whereas bone is grainy and coarse. The difference between ivory and bone could be ascertained by physical examination of the León artifact, but very few researchers have been allowed to handle the object, and no samples may be taken. Roesdahl reports that Jan Skamby Madsen, who personally examined the casket in July 1999, referred to it as bone, ${ }^{15}$ nevertheless, I caution that he was a museum director and a Viking ship scholar, not a specialist in the study of bone and ivory.

Many scholars seem to have merely conjectured about the raw material of the León box. For instance, Antonio Viñayo reports that the little León cylinder is made of reindeer antler, perhaps assuming that since the style is Scandinavian, it must necessarily be made of a distinctly northern material. ${ }^{16}$ In 199o, a zoologist cited by Roesdahl examined photographs of the piece and determined that it is made of antler from the red deer (Cervus elaphus), although he

10 Gómez-Moreno, Catálogo monumental de España, 1:195; vol. 2, figs. 195-196.

11 Xavier Dectot, "Quand l'ivoire venait de la mer. De quelques aspects du commerce de l'ivoire des mammifères marins brut et sculpté au Moyen Âge. When Ivory Came from the Seas. On Some Traits of the Trade of Raw and Carved Sea-mammal Ivories in the Middle Ages," Anthropozoologica 53/1 (2018): 1-28, esp. 3-7.

12 The Art of Medieval Spain. AD 500-1200 (New York: Metropolitan Museum of Art, 1993), 256, no. 121; Gaborit-Chopin, Elfenbeinkunst im Mittelalter, 195, no. 84.

13 Goldschmidt, Die Elfenbeinskulpturen aus der romanischen Zeit, 57, no. 298; Roesdahl, "From Scandinavia to Spain," 354. Roesdahl notes Goldschmidt published the León piece in a volume devoted to Romanesque works because he became aware of it too late to include it in his two volumes on Carolingian and Ottonian ivory sculpture.

14 Fuglesang, "Animal Ornament," 165; and Ann Christys, Vikings in the South: Voyages to Iberia and the Mediterranean (London: Bloomsbury Publishing, 2015), 7.

15 Roesdahl, "From Scandinavia to Spain," 354.

16 Antonio Viñayo González, Colegiata de San Isidoro (León: Edilesa, 1998), 46. 
admitted that it is difficult to distinguish red deer antler from reindeer antler. ${ }^{17}$ Several writers now refer to the material as deer-antler or only antler without stipulating the particular species of animal from which it comes. ${ }^{18}$ Antlers are the tough outgrowth of bone on cervids (animals of the deer family) that are shed every year, whereas horns on bovines (that is, cattle), sheep, and goats are permanent modified skin tissue. ${ }^{19}$ Horn, in particular, can be worked into very thin, flexible sheets and is often used for decorative work, such as panels placed over a wooden base. Some confusion between antler and horn may result because the word for antler in some languages is essentially deer horn, ${ }^{20}$ although Arthur MacGregor notes that the hollow structure of horn has "nothing in common with the material of deer antler," which although porous in the core is solid throughout. ${ }^{21}$ Furthermore, only antler has points or tines, extensions that bifurcate from the major branches of antlers. Although scholars have proposed various raw materials as candidates for the body of the León box, the argument that it was made of antler is clinched by the fact a projecting animal-head on the piece was carved from a small tine of an antler that jutted out from its main branch (see Figure 9.2).

\section{Why Is the Box Considered Scandinavian?}

The León object is linked with Scandinavia because the carvings on it are executed in one of the Nordic animal styles of the Viking Age that is known as the Mammen style, named after the inlaid design on a ceremonial axe from the site of Mammen on the Jutland peninsula of Denmark. ${ }^{22}$ The Viking Age dates from ca. A.D. 750 through ca. 1100, and the Mammen phase is dated by James Graham-Campbell from ca. 960 until ca. 1000/1025. ${ }^{23}$ The León piece also exhibits some characteristics that may be identified with the following style, Ringerike, which gradually replaces the earlier Mammen style around

\footnotetext{
17 Roesdahl, "From Scandinavia to Spain," 354.

18 Including James Graham-Campbell, Viking Art (London: Thames and Hudson, 2013), 114.

19 Arthur MacGregor, Bone, Antler, Ivory and Horn. The Technology of Skeletal Materials since the Roman Period. (London: Croom Helm, 1985), 1-22.

20 For instance, Polish róg = horn; róg jelenia = antler (deer horn); and Spanish asta de ciervo, ast $a=$ horn, ciervo $=$ deer; also, cuerno de ciervo $=$ hart's horn .

21 MacGregor, Bone, Antler, Ivory and Horn, 20-21, 187.

22 Lennart Karlsson, Nordisk Form om Djurornamentik, Studies, 3 (Stockholm: Statens Historiska Museum, 1983), 123-125, relates the history of the use of this style name, initiated by Sune Lindqvist, "Yngre vikingastilar," in Konst, ed. Haakon Shetelig, Nordisk Kultur, 27 (Stockholm: Albert Bonniers Förlag, 1931), 144-179, esp. 148. 


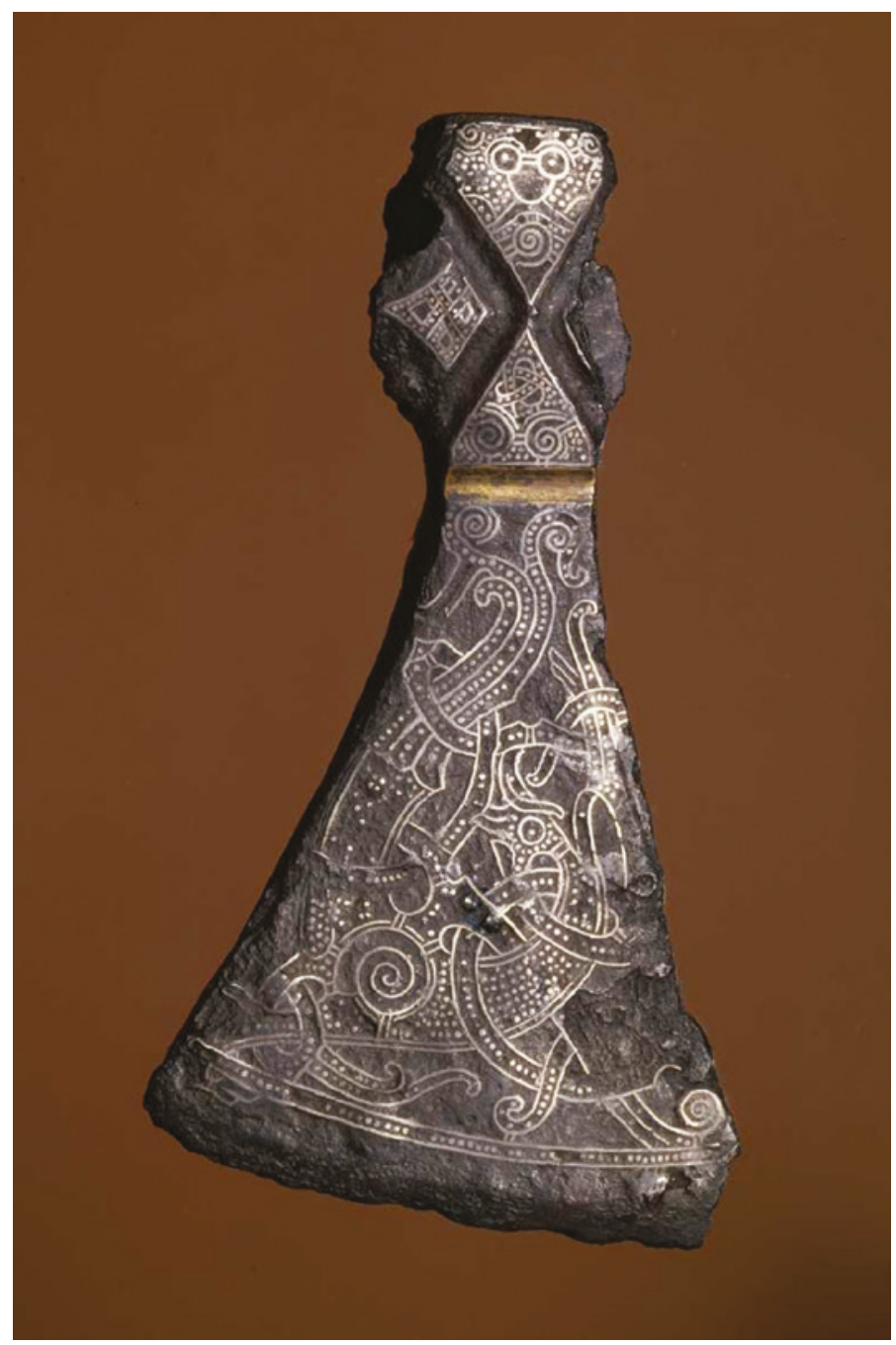

FIGURE 9.3 Mammen axe. From Mammen (Bjerringhøj), Jutland, Denmark. Iron with silver and gold inlay, $17.5 \mathrm{~cm}$. (Nationalmuseum, Copenhagen, Denmark, Inv. No. C133). PHOTO: LENNART LARSEN. CREATIVE COMMONS LICENSE CC-BY-SA

A.D. 1000. ${ }^{24}$ The chronology is based on typological distinctions, sometimes supported by stratigraphic data from excavated finds.

The main motif of the Mammen style, seen prominently on the eponymous axe from northern Jutland in Denmark (Figure 9.3) and the Jelling stone (Figure 9.4) — a large stone inscribed with Scandinavian runic writing

Fuglesang, “Animal Ornament," 166. 


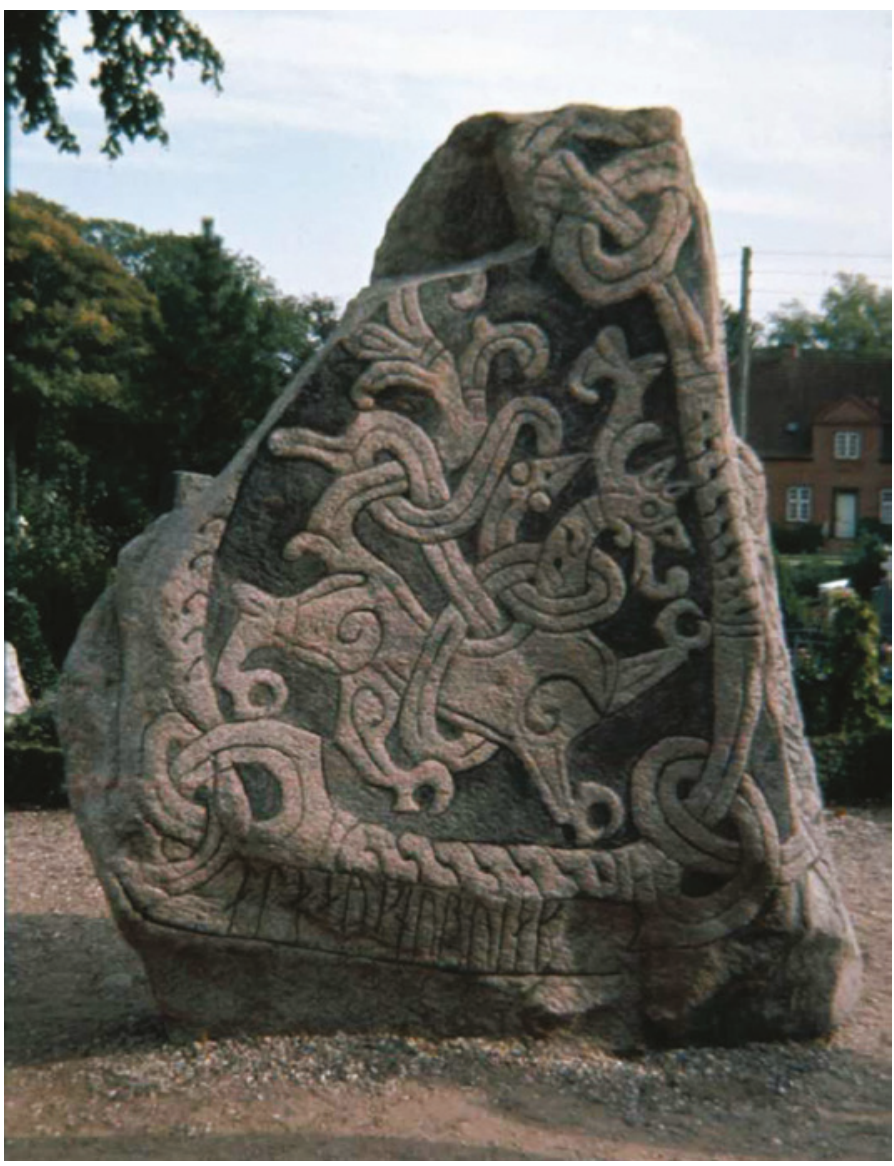

FIGURE 9.4 Jelling stone, great beast face. At Jelling, Jutland, Denmark. Red-veined gray granite, $2.4 \mathrm{~m}$. high $\times 2.9 \mathrm{~m}$. wide.

PHOTO: CREATIVE COMMONS LICENSE CC-BY-SA

at Jelling in southern Jutland - is a relatively large animal or bird that has a rather small head, a round eye, and spirals marking shoulder, hip, and bird-wing joints. ${ }^{25}$ The animal's legs end in claws, and elongated tendrillike offshoots called lappets extend from the head and limbs and terminate in circular lobes. Contours are often doubled, and the internal spaces are filled with a texture of circular flat discs by convention called pelleting in Viking-Age art. ${ }^{26}$ The large animal or bird interlaces with one or more narrow

25 David M. Wilson, "Part II," in Viking Art, ed. David M. Wilson and Ole Klindt-Jensen (London: George Allen and Unwin, 1980), 85-16o, esp. 119-120. Description of pelleting in Wilson, Viking Art, 112 and 125. 
snake-like creatures; some interstices between snakes are cut through the antler to form perforations. To those who are not familiar with animal-style art, the design carved on the León cylinder may look utterly confusing. To those who are familiar with the Scandinavian Viking-Age styles, the motif can be recognized as a bird. The specific vocabulary used to describe Viking styles, including lappets, pelleting, offshoots, and transversal branching, has been systematized through decades of refinement, especially by Fuglesang and David M. Wilson, ${ }^{27}$ and these details enable recognition of the style of the León piece.

\section{What Is Carved on the León Box?}

The composition carved on the León box can be discerned most clearly when the three-dimensional projecting part-which is carved from one of the antler tines-is positioned at the top, although most images of the work are published with the head at the bottom and are thus shown in what appears to be an upside-down position, considering the upright orientation of threedimensional bird and animal heads that project from other Viking-Age objects (discussed below). With the protuberance at the top, the viewer may be able to recognize a bird's head projecting from the top of the cylinder like a gargoyle (Figure 9.5). Roesdahl consistently illustrates the bird head of the León piece at the top; however, sometimes she refers to it as a handle and other times as an ear, which is unnecessarily confusing. ${ }^{28}$ Eduardo Morales Romero, who has brought the Viking piece to the attention of both Spanish and Danish readers, includes several images of the box from various viewpoints featuring the head at the top. ${ }^{29}$ Fuglesang and Davies display the León box on its side, viewed obliquely from the bottom and with the current lid open, in a compromise position also shown by Roesdahl, who presents a right-side-up

27 Signe Horn Fuglesang, Some Aspects of the Ringerike Style: A Phase of nth-Century Scandinavian Art, Mediaeval Scandinavia Supplements, 1 (Odense: Odense University Press, 1980); Wilson, Viking Art.

28 Roesdahl, "Cammin-Bamberg-Prague-Léon [sic]," 550-552, Fig. 8 (p. $55^{2}$ refers to the projection as a handle); Roesdahl, "Viking Art in European Churches," 157-158, Figs 7-8 (p. 158 refers to the ear); and Roesdahl "From Scandinavia to Spain," 353, figs 33.2-33.3 (p. 355 refers to the $e a r)$.

29 Eduardo Morales Romero, "Arte vikingo. La cajita de San Isidoro de León," Revista de Arqueología 121 (1991): 40-47; Eduardo Morales Romero, "San Isidoro-æsken i León," in Vikingerne på Den Iberiske Halvø, ed. Christopher Bo Bramsen (Madrid: Dronning Isabella Fonden, 2004), 118-125. 


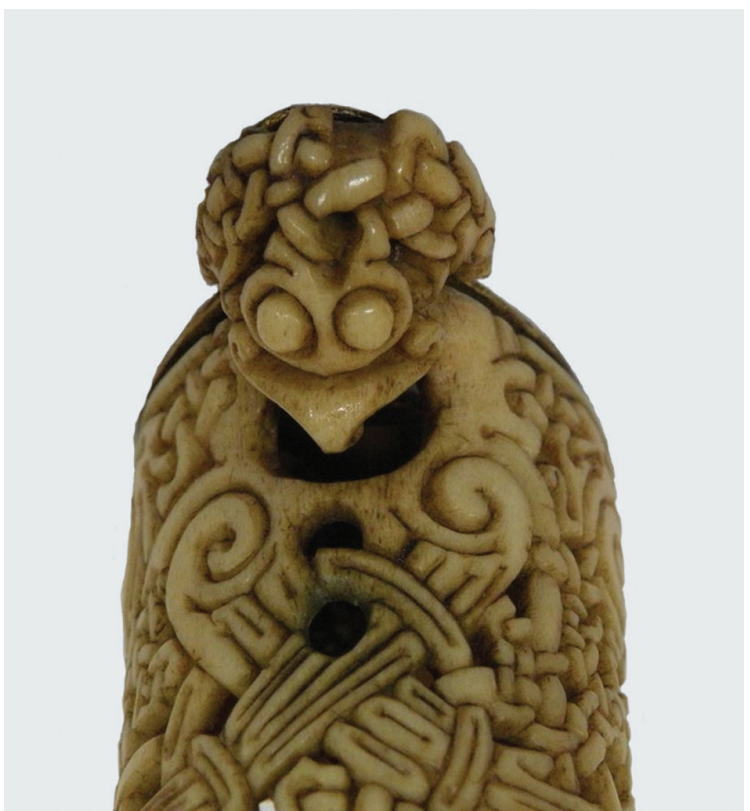

FIGURE 9.5 León cylinder, detail. Bird head facing downward. Red deer antler and gilt copper alloy, 4.4 cm. (Museo de la Real Colegiata de San Isidoro de León, Inv. No. IIC-3o89-002-0oog). See also Figs. 2.1a, 2.1b.

PHOTO: THERESE MARTIN

view. ${ }^{30}$ Both Goldschmidt and Graham-Campbell are aware that they illustrate it upside-down. ${ }^{31}$ Other authors seem oblivious to the motif represented on the casket and show the bird's head at the bottom. Most conspicuously perpetuating this misleading view are the photographs on the cover of the book by Christys and accompanying the entry for the 1993 Metropolitan Museum exhibition catalogue. ${ }^{32}$

With the carved, three-dimensional head placed at the top of the León composition, the primary figure of a bird of prey with splayed-out wings and tail feathers becomes visible. In addition to the major motif of the bird, additional serpentine creatures, usually referred to as snakes, interlace with the large bird. Five of the snakes fill the rectangular field that encircles the cylinder and two

$30 \quad$ Fuglesang, "Animal Ornament," 166, Fig. 7; Davies, "Treasure-A View from the South," 542, Fig. 1; and Roesdahl, "From Scandinavia to Spain," 356, fig. 33.4.

31 Goldschmidt, Die Elfenbeinskulpturen aus der romanischen Zeit, Plate 74, nos. 298 a, b.; and Graham-Campbell, Viking Art, 114 . 


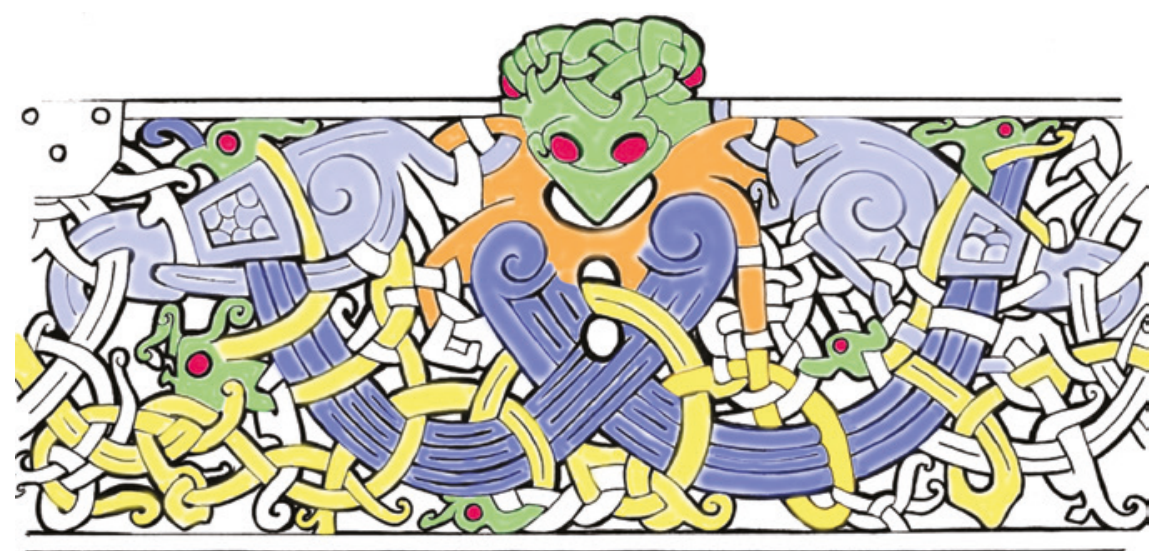

FIGURE 9.6 León cylinder.

SOURCE: COLORED DRAWING BY NANCY L. WICKER, ADAPTED FROM DRAWING BY LOUISE HILMER, IN ROESDAHL, "FROM SCANDINAVIA TO SPAIN: THE LEÓN RELIQUARY,” 357, FIGURE 33.5

small ones that are difficult to see in a flat drawing nestle on either side of the three-dimensional bird head. In my drawing, I follow the standard for representing Scandinavian animal-style art - with the eyes red, heads green, body orange, and limbs blue - established by Bengt Händel to help modern viewers recognize the various parts (Figure 9.6). ${ }^{33}$ However, I add additional colors to make a more discriminating palette with the body of the major bird in orange but the bodies of the snakes in yellow. I also distinguish the bird's wings from its legs with dark blue and light blue, respectively. The motifs on the León box are recognizably similar to designs on other Viking-Age objects. In fact, many objects are comparable to this piece in one way or another, reflecting similarity of shape or function, motifs and styles, and materials.

Only a few Viking-style objects can be compared to the 4.4-cm León piece on the basis of its cylindrical shape and its possible function. Comparable objects may include knife handles, needle cases, and salt reservoirs, as well as unidentifiable cylinders, from the Viking homeland and its diaspora, stretching from

33 Colors used by Bengt Händel have become standard since Wilhelm Holmqvist, Vår Tidiga Konst (Stockholm: LTs förlag, 1977), 125-128. I adapted my diagram from a drawing by Louise Hilmar in Roesdahl, "From Scandinavia to Spain," 357, fig. 33.5. 


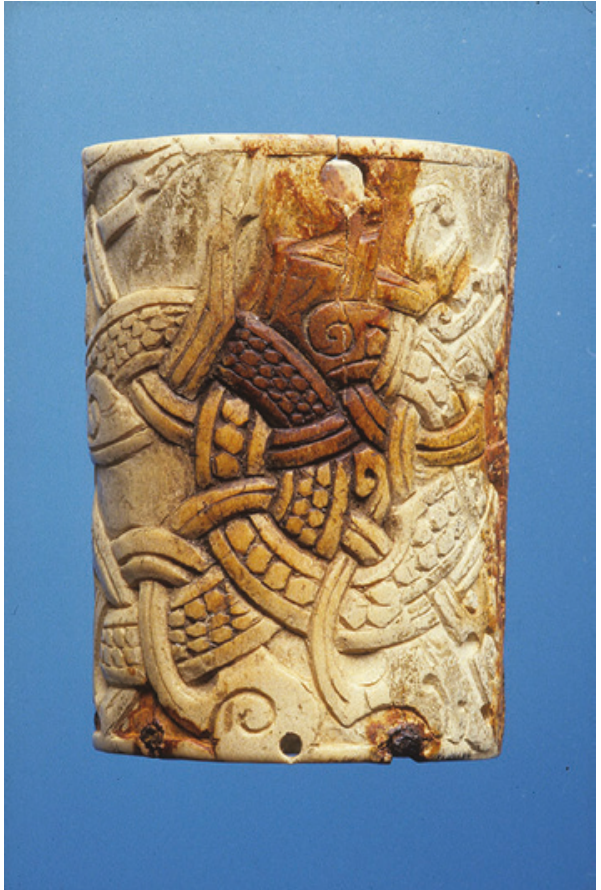

FIGURE 9.7

Bone sleeve. From Årnes, Møre og Romsdal, Norway. Bone, $6 \mathrm{~cm}$. (NTNU Vitenskapsmuseet, Trondheim, Norway. Inv. No. T18308).

SOURCE: CREATIVE COMMONS LICENSE CC-BY-SA 4.0.

Norway and Sweden to England, Scotland, and Poland. Graham-Campbell calls a similar 6-cm carved bone found at Årnes in Norway a cylindrical mount, Wilson refers to this object as a sleeve, and Fuglesang proposes it is a bone mount for a knife sheath (Figure 9.7). ${ }^{34}$ Other related objects include a 5.1$\mathrm{cm}$-high cylinder of deer antler found in a settlement area at the mouth of the Oder River at Wolin in Poland and a $7 \cdot 7-\mathrm{cm}$ bone cylinder found at Bornais on South Uist in the Hebrides, Scotland. 35 The piece from Wolin resembles the Årnes sleeve as both approximate true cylinders, while the sides of the

34 James Graham-Campbell, Viking Artefacts: A Select Catalogue (London: British Museum, 1980), 147, no. 495; Wilson, Viking Art, 128; and Fuglesang, Some Aspects of the Ringerike Style, 127 .

35 For Wolin, see Błaźej M. Stanisławski, Jómswikinowie z Wolina-Jómsborg—studium archeologiczne przenikania kultury skandynawskiej na zeimie polskie (Wroclaw: Institute of Archaeology and Ethnology, Polish Academy of Sciences, 2013), 146-148, 334, fig. 49c. For Bornais, see Niall Sharples, "A Find of Ringerike Art from Bornais in the Outer Hebrides," in Land, Sea and Home, ed. John Hines, Alan Lane, and Mark Redknap, Society for Medieval Archaeology Monograph 20 (Leeds: Maney, 2004), 255-272, esp. 265; and Sharples, "Telling the Story of the Hebridean Norsemen," Stornoway Gazette, 16 June 2017, color photograph. 
Bornais object slope inward forming a squat, wide container. Fragments of an 8-cm-long bone object from Å, Snillfjord, Trøndelag, Norway, formed a cylinder smaller in diameter than the Årnes, Bornais, and León pieces, and Oddmun Farbregd and Fuglesang identify it as a needle-case. ${ }^{36}$ Sten Tesch tentatively proposes that the León box as well as other cylinders and T-shaped containers made of antler and found in England, Norway, Russia, Sweden, and Ukraine, all held salt. ${ }^{37} \mathrm{He}$ admits that his interpretation of the pierced León container as a salt vessel may seem speculative, but he suggests that its contents could have been wrapped in linen. The Årnes, $\AA$, and Bornais pieces were found in female graves that were most likely not Christian, and the Wolin object was found without context. None of the comparable cylindrical items of osseous materials are documented to have been used as reliquaries, and none are executed in openwork technique like the León box. Thus, it seems unlikely that this container now housed in Spain was intended to be reliquary.

\subsection{Comparable Motifs and Styles on Other Objects}

The motifs and styles seen on the León piece resemble those on objects as diverse as small cylinders, large jewelry caskets, ceremonial axes, and monumental raised stones, distributed from Scandinavia to the British Isles and Eastern Europe. The comparable cylindrical objects described above are of the Mammen style and the subsequent animal-art style known as Ringerike, named for carved stones in the district by that name in Norway. ${ }^{38}$ The fragmentary cylinder from $\AA$, Snillfjord, displays the Mammen style and is stylistically similar to the León container. ${ }^{39}$ The carving on the Wolin cylinder is difficult to comprehend but seems to be of Mammen style and probably contemporary with the closely related León example. Spiral joints, and pelleting are visible

36 Oddmun Farbregd, "Litt vikingkunst i to nye gravfunn frå Tröndelag," Nicolay 9 (1971): 913, esp. 11, fig. 4; Fuglesang, Some Aspects of the Ringerike Style, 127-128; and Signe Horn Fuglesang, "The Axehead from Mammen and the Mammen Style," in Mammen. Grav, kunst og samfund $i$ Vikingetid. Jysk Arkæologisk Selskabs Skrifter, 28 (Århus: Aarhus Universitetsforlag, 1991), 91, no. 18.

37 Sten Tesch, "Cum grano salis—Salt and Prestige:LateViking Age and Early Medieval T-Shaped and Cylindrical Salt Containers," in Cultural Interaction between East and West: Archaeology, Artefacts and Human Contacts in Northern Europe during the Pre-and Early History, ed. Ulf Fransson, Marie Svedin, Sophie Bergerbrant, and Fedir Androshchuk (Stockholm Studies in Archaeology, 44. Stockholm: Stockholm University, 2007), 227-235, esp. 230.

38 Wilson, Viking Art, 134; Fuglesang, Some Aspects of the Ringerike Style, 14. Fuglesang notes that the two styles have much in common, and she describes their similarities and differences.

39 Farbregd, "Litt vikingkunst i to nye gravfunn;" Fuglesang, Some Aspects of the Ringerike Style, 18, 127-28, pl. 107D; and Fuglesang, "Axehead from Mammen," 91, no. 18. 
on it, as well as some smaller, snake-like elements that interlace with larger double-contoured animals; however, the entire composition cannot be seen clearly because of poor preservation of the artifact. ${ }^{40}$ The decoration on the Årnes cylinder - three interlaced animals with round eyes, spiral hips, and a pelleted texture that fills the space between double contours-also resembles the León box, as recognized by Sverre Marstrander. ${ }^{41}$ Wilson identified its style as primarily Mammen, yet transitional to the later Ringerike style because of the tautness of the animals' elongated vegetal extensions. ${ }^{42}$ Thus, it is typologically dated somewhat later than the León object. Although the Bornais object is comparable to the León container in its girth, the carving with long, vegetal extensions with spiral terminals that emanate from the animal's head is of the Ringerike rather than Mammen style. Therefore, it too was most likely made later than the León container. ${ }^{43}$ The T-shaped and cylindrical containers discussed by Tesch include geometric, figurative, and animal-style motifs; of his examples, only the Årnes piece and one from St. Martin-le-Grand in London display Mammen or Ringerike animal styles and resemble the León carving. ${ }^{44}$ The 4.7-cm bone cylinder from St.-Martin-le-Grand resembles the León piece in its proportions, but its style is classic-phase Ringerike, markedly different from the León Mammen style. ${ }^{45}$ Of all the small cylindrical objects under consideration here, the Årnes, $\AA$, and Wolin pieces are the most similar stylistically to the León container. Although these diminutive cylindrical artifacts bear both stylistic and formal affinities with it, the most commonly cited comparisons to the little box are motifs on sizable objects of a different character.

The Bamberg and Cammin caskets, two large containers that were formerly used as reliquaries and preserved in church treasuries, are the objects that are most commonly associated with the León box. Both pieces were published by Goldschmidt in 1918 and studied in detail by Arnold Muhl. ${ }^{46}$ The Bamberg casket was kept in St. Stephen's church in Bamberg, Germany, where it is assumed

40 Stanisławski, Jómswikinowie z Wolina, 146-48, 334, fig. 49c; and Błaźej M. Stanisławski, "Sztuka wikińska z Wolina," Średniowiecze Polskie i Powszechne 4 (2007):28-5o, fig. 19, and English summary 49-50.

41 Sverre Marstrander, "Funn av beinholk med dekor i Jellingestil," Viking 27 (1964): 169-171.

42 Wilson, Viking Art, 128.

43 Sharples, "Find of Ringerike Art from Bornais;" and Sharples, "Telling the Story of the Hebridean Norsemen," color photograph.

44 Tesch, "Cum grano salis;" Graham-Campbell, Viking Artefacts, 302, no. 500, illustrates the St.-Martin-le-Grand cylinder.

45 Graham-Campbell, Viking Artefacts, 148, no. 5 oo.

46 Adolph Goldschmidt, Die Elfenbeinskulpturen aus der Zeit der karolingischen und sächsischen Kaiser VIII.-XI. Jahrhundert, Die Elfenbeinskulpturen, 2 (Berlin: Verlag Bruno Cassirer, 1918. Reprint, Berlin: Deutscher Verlag für Kunstwissenschaft, 1970), 2:58-59, 
to have been a reliquary casket through the medieval period, although the lock on its cover hints that it may have come to Bamberg as a secular jewelry box. The $26-\mathrm{cm}$-square Bamberg box has an oak frame covered with walrus ivory panels bound by copper-alloy mounts. ${ }^{47}$ The panels show a profuse texture of pelleting that fills the double-contours of Mammen-style birds and quadruped animals. The 62-cm-long Cammin casket was housed in the cathedral at Kamień Pomorski, Poland (formerly Cammin, in Prussian Germany), near the shore of the Baltic Sea, until it was destroyed by bombing at the end of World War II. Fortunately, Goldschmidt had published numerous detailed photographs in 1926, and copies of the object had been made before its destruction. The Cammin casket, with a lock on its side, probably consisted of elk antler panels that covered a wooden frame, anchored by gilt copper-alloy straps. ${ }^{48}$ Its motifs of fantastic animals, birds, and masks are quite similar to those on the Bamberg casket, and the birds closely resemble the one on the León box. Wilson proposes that the Cammin and Bamberg caskets were made in the same workshop, although there are minor differences between the carving on the Bamberg walrus ivory and the Cammin elk antler panels that may result from the disparity in materials. ${ }^{49}$ Notably, the panels on both caskets are solid rather than carved in openwork like the León piece.

\subsection{Comparable Styles on Metal and Stone}

Mammen-style motifs comparable to those on the León box also embellish objects made from non-osseous materials, namely, metal and stone, as on the 17.5-cm style-namesake Mammen axe of iron with silver inlay and the large (2.4 $\mathrm{m}$. high $\times 2.9 \mathrm{~m}$. wide) granite stone raised at Jelling. The rune-inscribed stone is remarkable as a historic monument raised by King Harald Bluetooth (r. 940985 ) and also for its display of the iconic representation of the major four-footed beast depicted in Mammen style. ${ }^{50}$ The style is also visible on Norse runic stones

nos. 189 and 192; Arnold Muhl, "Der Bamberger und der Camminer Schrein. Zwei im Mammenstil verzierte Prunkkästchen der Wikingerzeit," Offa 47 (1990): 241-420.

47 Wilson, Viking Art, 125, states that the Bamberg panels are of walrus ivory. Muhl, "Der Bamberger und der Kamminer Schrein," 259-261, asserts that only microscopic or scientific analysis can determine the raw material, not visual inspection.

48 Muhl, "Der Bamberger und der Kamminer Schrein," 304-305, cites early 2oth-century scholars who examined Cammin panels and concluded that they were elk antler since the material was coarser than ivory. Wilson, Viking Art, 128, states that it was "elk-horn."

49 Wilson, Viking Art, 126.

50 ErikMoltke, Runerne iDanmarkog dere oprindelse (Copenhagen:Forum, 1976),166-178; and Moltke, Runes and Their Origins: Denmark and Elsewhere (Copenhagen: Nationalmuseets Forlag, 1985), 202-220. 
erected on the Isle of Man in the Irish Sea, where Scandinavian Vikings raided in the early ninth century and settled by the next century. ${ }^{51}$ In addition, the León bird motif with nearly symmetrical outspread wings is similar to a Mammen-style bird depicted at the top of one side of a $2.7-\mathrm{m}$ tall rune stone at Alstad in the Ringerike district of Norway. ${ }^{52}$ These conspicuous monuments are witnesses to the wide distribution of the Mammen style as carved on various two-dimensional media-from stationary stones to easily transportable small craft objects - yet the style can also be conceived in three dimensions.

The projecting head made from the antler tine at the top of the León box can be compared to numerous small three-dimensional metal mounts on other Viking-Age objects decorated in the Mammen style and found in Denmark, Germany, and Poland. The León bird head especially resembles numerous metal bird and animal heads that jut out as protomes from the Cammin and Bamberg caskets, while a 4.2-cm gilt bronze strap slide from Jelling (Figure 9.8) shows a fully sculptural version of a bird with wings folded over itself. ${ }^{53}$ The sculptural quality of these pieces with prominent eyes and beak can also be observed on a 5.1-cm silver so-called Thor's hammer amulet from Scania in Sweden (Figure 9.9) and a fragment of a gold filigree pendant found at the Fyrkat fortress in Denmark, both illustrated by Morales Romero, as well as on a small gilt copper-alloy bird found at Tissø in Zealand, Denmark. ${ }^{54}$ A complete specimen of the type from Fyrkat is known from Sigtuna, Sweden, as well as numerous similar examples also in gold from Hiddensee Island near Rügen on the Baltic coast of Germany. ${ }^{55}$ Roesdahl points out that comparable threedimensional birds also decorate Viking-Age horse collars from Mammen, Møllemosegård, and Søllested. ${ }^{56}$ Even though the bird's head on the León piece is made of antler, its design is similar to numerous heads in metal that serve as terminals or protomes on various Viking-Age objects.

51 David M. Wilson, Manx Crosses: A Handbook of Stone Sculpture 500-1040 in the Isle of Man (Oxford: Archaeopress, 2018), 79-124.

52 Wilson, Viking Art, 131, fig. 59. The other side of the stone displays the Ringerike style.

53 Else Roesdahl, "The Northern Mound: Burial Chamber and Grave Goods," Mediaeval Scandinavia 7 (1974): 208-223, esp. 218 and fig. 8.

54 Morales Romero, "Arte Vikingo," 42. For the Scanian Thor's hammer, see Graham-Campbell, Viking Art, 169. For the Fyrkat fragment, see Barbara Armbruster and Heidemarie Eilbracht, Wikingergold auf Hiddensee, Archäologie in Mecklenburg-Vorpommern, 6 (Rostock: Hinstorff, 2010), 162. For the Tissø bird, see Michaela Helmbrecht, "A Winged Figure from Uppåkra," Fornvännen 107/3 (2012): 171-178, esp. 174.

55 For Sigtuna, see Graham-Campbell, Viking Art, 75. For Hiddensee, see Armbruster and Eilbracht, Wikingergold auf Hiddensee, 94-97.

56 Roesdahl, "The Northern Mound," 217. 


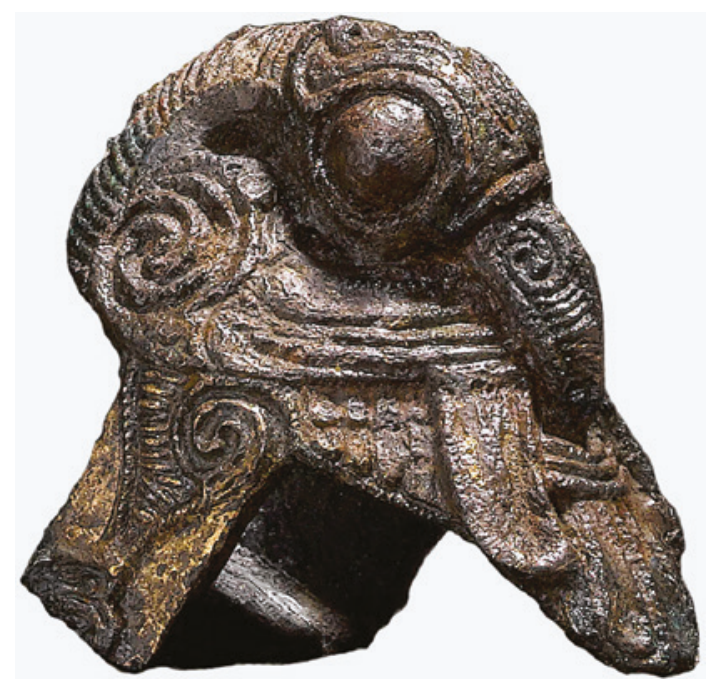

FIGURE 9.8

Jelling strap slide. Jelling, Jutland, Denmark. Gilt bronze, $4.2 \mathrm{~cm}$. (Nationalmuseum, Copenhagen, Denmark, Inv. No. CCCLXXIII). PHOTO: ROBERTO FORTUNA AND KIRA URSEM. CREATIVE COMMONS LICENSE CC-BY-SA

Besides parallels to the carving on the León antler cylinder, its openwork metal lid and base of gilt copper-alloy also have affinities with Mammen-style metalwork in Scandinavia. Roesdahl brings attention to three metal hinges found at Jelling that provide evidence of a square casket perhaps similar to the one from Bamberg, and a locking mechanism and other metal fittings found at Haldum near Aarhus in eastern Jutland suggest another casket of similar construction. ${ }^{57}$ Greta Arwidsson and Håkan Thorberg note a casket found at Birka in Sweden with metal hasps that terminate in animal heads. ${ }^{58}$ The metal lid and base of the León box are similar in design to small circular brooches found in Scandinavia, as illustrated by Ingmar Jansson. ${ }^{59}$ Openwork metal was commonly used for Viking brooches, and works that are deeply layered and undercut rather than completely pierced are displayed in metal as well as wood-not

57 For Jelling, see Roesdahl, "The Northern Mound;" and Roesdahl, "A Forgotten Casket Hinge from the Burial Chamber at Jelling," Mediceval Scandinavia 8 (1975): 21-26. For Haldum, see Jens Jeppesen and Marianne Schwartz, "Fornemt skrin—i en kvindegrav fra vikingetid," Kuml: Årbog for Jysk Arkceologisk Selskab 56 (2007): 123-147.

$5^{8}$ Greta Arwidsson and Håkan Thorberg, "Kästchen und Schachteln," in Birka II:3. Systematische Analysen der Gräberfunde, ed. Greta Arwidsson, Birka Untersuchungen und Studien, 2, no. 3 (Stockholm: Kungliga Vitterhets Historie och Antikvitets Akademien, 1989), 113-121, esp. 114, fig. 23:3.

59 Ingmar Jansson, "Kleine Rundspangen," in Birka II, 1. Systematische Analysen der Gräberfunde, ed. Greta Arwidsson, Birka Untersuchungen und Studien, 2, no. 1 (Stockholm: Kungliga Vitterhets Historie och Antikvitets Akademien, 1984), 58-74, esp. 61, fig. 8:2. 


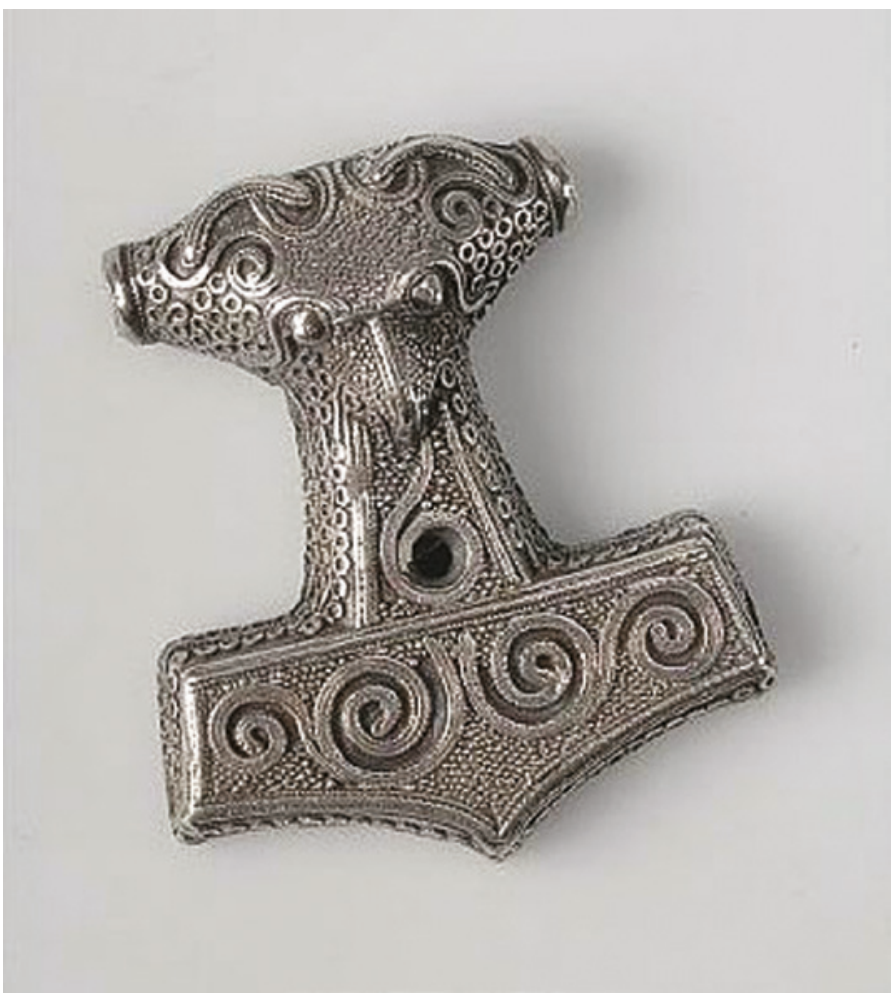

FIGURE 9.9 Thor's hammer. Scania, Sweden. Silver, 5.1 cm. (S HM 9822:810). PHOTO: GABRIEL HILDEBRAND SHM 2011-11-08. CREATIVE COMMONS LICENSE CC-BY-SA 4.0

least in the wood-carvings on the Viking ship from Oseberg in Norway. ${ }^{60} \mathrm{Al}-$ though several caskets resemble the León work by combining ivory or antler carving with metal fittings, the piercing in both the metal and the antler portions of the little box in Spain is unparalleled. However, there is nothing about the technology of its construction that would indicate where it was produced.

\section{$6 \quad$ Where Was the León Box Made?}

The Mammen style has often been considered a specifically Danish style, so one might conclude that the León box was made in Denmark; however,

6 Ole Klindt-Jensen, "Part I," in Viking Art, ed. David M. Wilson and Ole Klindt-Jensen (London: George Allen and Unwin, 1980), 25-83, esp. 49, 54, 56, and 61. Klindt-Jensen writes about the plastic spatial effects of the early Viking styles. 
Wilson demonstrates that many works in this style have been found outside Scandinavia — in England, Germany, Poland, Russia, Scotland, and Ukraine. ${ }^{61}$ Portable objects including ivory and antler-work as well as metalwork could have been made anywhere across the Viking world from Russia to the British Isles by an itinerant or settled craftworker. Only the large raised Viking-style stones can be assumed to have been carved in place, whether in Scandinavia or the Isle of Man, where many monumental Viking carved stones still stand. P. M. C. Kermode suggested that the easily portable León box could have been made by an itinerant Scandinavian craftworker in a Manx workshop, due to its similarities in style to those carvings, particularly those at Kirk Michael and Kirk Braddan. ${ }^{62}$ However, until remains of Viking antler-working are discovered on the Isle of Man, it is more straightforward to propose that the León piece was made in one of the well-known craft centers such as at Ribe (Denmark), Birka (Sweden), Hedeby (Germany), Wolin (Poland) and sites in the Nordic-colonized British Isles including York and Dublin, where workshop debris has been excavated. Kristina Ambrosiani was able to distinguish red deer antler from elk antler at Birka and Ribe by microscopic analysis, and her work on the workshops there laid the groundwork for future studies. ${ }^{63}$ The range of red deer stretched from North Africa to southern Scandinavia, ${ }^{64}$ and pieces of antler could be transported easily; nevertheless, sourcing raw materials may some day offer a way to trace the origin of the León box.

Steven Ashby notes that "in the Viking Age the preferred material was deer antler" for comb-making, ${ }^{65}$ and it also was used to craft other artifacts. Although there are minor technical differences between carving antler, walrus ivory, and bone, all of these materials could be worked in the same workshop, depending upon which raw materials were available and what objects were to be made. At a twelfth-century bone and antler workshop in Lund, Sweden, a fragmentary chess piece of walrus ivory was found with comb-making

\footnotetext{
61 Wilson, Viking Art, 132.

62 P.M.C. Kermode, Manx Crosses (London: Bemrose and Sons, 1907. Reprinted with an introduction by D. M. Wilson [Balgavies, Angus, Scotland: Pinkfoot Press, 1994]), 57, no. 105 for Kirk Michael, and nos. 108-9 for Kirk Braddan See also Wilson, Manx Crosses, 90-93, especially the stones now numbered 135 and 136 for Kirk Braddan.

63 Kristina Ambrosiani, Viking Age Combs, Comb Making and Comb Makers in the Light of Finds from Birka and Ribe, Stockholm Studies in Archaeology, 2 (Stockholm: Stockholms Universitet, 1981), 36 .

64 Steven P. Ashby, A Viking Way of Life: Combs and Communities in Early Medieval Britain (Stroud, Gloucestershire: Amberley, 2014), 23-24.

65 Ashby, Viking Way of Life, 21.
} 
debris. ${ }^{66}$ In a recent study, Johnny Karlsson traces the changing use of various osseous materials - red deer antler, reindeer antler, elk antler, walrus ivory, and bone-in middle Sweden from the Viking Age into the medieval period according to the availability of resources through time and space, and he offers the following observations: ${ }^{67}$ in general, red deer was imported during the Viking Age into the trading center at Birka from the south, especially Frisia and the west Slavic region, whereas reindeer antler was connected to the fur trade with the Sami in the North; the early eleventh century at Sigtuna is marked by red deer debris, but by the twelfth century, ties to the Atlantic via Norway were strengthened and walrus ivory became more common; and finally, according to Karlsson, bone became prominent when the raw material source changed from hunted and collected antler to the use of bones of butchered domestic animals in urban environments. Although we cannot localize the place of production of the León box, its use of red deer is consistent with Karlsson's findings for Viking Age Birka and Sigtuna in Sweden and also with Ashby's comment on its popularity during this period in the British Isles and Scandinavia. The chronology of working deer antler in these areas agrees with the stylistic assessment of an approximate date of around A.D. 1000 for the Mammen style box. If we assume that the little Viking-style object was made in the Viking homeland or areas they colonized, we must ask how it reached Iberia.

\section{How Did the León Box Reach the Iberian Peninsula?}

Although Viking raids into Iberia are documented from the mid-ninth century onwards, ${ }^{68}$ it seems unlikely that the little box in the San Isidoro treasury was a trifle misplaced by a marauding invader. If small-scale attacks continued as late as the twelfth century even in northern parts of the peninsula, the Vikings' contacts with other Europeans also took various forms. In fact, exotic goods were exchanged across Europe for diverse reasons, and the León box may be an

66 Else Roesdahl and David M. Wilson, eds., From Viking to Crusader: Scandinavia and Europe 800-1200 (New York: Rizzoli, 1992), 39o, no. 613.

67 Johnny Karlsson, Spill—om djur, hantwerk och nätverk i Mälarområdet under vikingatid och medeltid. Theses and Papers in Osteoarchaeology, 8 (Stockholm: Stockholms Universitet, 2016), 196-200 (English summary, 211-215).

68 Christys, Vikings in the South, 1; Iván Curto Adrados, Los vikingos y sus expediciones a la Península Ibérica, Sine Qva Non. Monografías de Historia Medieval, 2 (Madrid: Ediciones de La Ergástula, 2017); Arne Melvinger, Les premières incursions des Vikings en Occident d'après les sources arabes (Uppsala: Almqvist \& Wiksell, 1955); Helio Pires, "Viking Attacks in Western Iberia: An Overview," Viking and Medieval Scandinavia 9 (2013): 155-172. 
example of nonviolent interactions. Roesdahl proposes that this object, as well as the Cammin and Bamberg caskets, were "diplomatic gifts, presented by a king to kings or princes in various parts of Europe." ${ }^{69}$ However, not all the traffic in precious goods depended upon dignitaries. Davies discusses how both elite and commonplace goods were used as gifts and counter-gifts. ${ }^{70}$ Franco Valle traces pilgrims who brought gifts from afar to northern Iberia, especially to Santiago de Compostela but also to León, which was located on that important pilgrimage route. ${ }^{71}$ The exploits of Vikings in the early eleventh century also took various forms. A Viking demand for ransom to return three daughters they had captured in 1015 was documented, and repayment of another ransom a few years later was accompanied by a list of the items that were handed over, including "a cloak, a sword, a shirt, three pieces of linen, a cow, and some salt."72 The little León box is precisely the kind of small item that could be handled easily in such an exchange-a package made of a prized, exotic material and presumably containing desired goods, perhaps even salt as proposed above by Tesch, although I will suggest solid aromatics as a more likely substance. The little container may have changed hands several times before reaching San Isidoro.

Fuglesang assumes that the León box was originally a reliquary and states that it "strengthens the possibility that the Bamberg and Cammin caskets were originally reliquaries rather than secular boxes for jewelry or the like."73 However, this circular reasoning depends upon her assumption that the León cylinder was a reliquary, a position for which there is no solid evidence. In fact, the León container likely had an alternate function before it was given by a royal or aristocratic donor, perhaps in 1063 by King Fernando of León (r. 1037-1065) and Queen Sancha (d. 1067), who exerted royal authority alongside her husband, when the church was rededicated in St. Isidore's honor, or in the early twelfth century by Queen Urraca (r. 1109-1126), whose donation of relics collected from abroad to the church of San Isidoro in León has been studied by Therese Martin and is discussed in Chapter 2 of this volume. ${ }^{74}$ Roesdahl purports that the cylinder "may well have been in royal possession for some time before it came to San Isidoro, and it may first have been in another royal chapel or church in the region." ${ }^{75}$ Eventually relics of St. Nicholas were associated with the box,

69 Roesdahl, "Viking Art in European Churches," 159.

70 Davies, "Treasure-A View from the South," 554.

71 Franco Valle, "Viking Art in the Church," 32.

72 Christys, Vikings in the South, 96.

73 Fuglesang, "Animal Ornament," 165-166.

74 Therese Martin, Queen as King: Politics and Architectural Propaganda in Twelfth-Century Spain (Leiden: Brill, 2006), 15; Martin, "Caskets of Silver and Ivory." 
as documented by a small label mentioned by Ambrosio de Morales in $1565 .{ }^{76}$ Since the manufacture of the box ca. A.D. 1000 predates its alleged use as a reliquary container, how was it originally used and what were its contents?

\section{What Were the Original Use and Contents of the León Box?}

As noted earlier, Roesdahl proposes that precious Viking objects reached European royalty as diplomatic gifts. The precise movements of the León box as well as the Cammin and Bamberg caskets are undocumented, but Roesdahl repeats long-established explanations for how the two large caskets reached their destinations. The Cammin casket may have reached Kamien due to its proximity to Viking Wolin (also known as Jumne), where the Danish King Harald Bluetooth established a residence after defeat, according to Adam of Bremen. ${ }^{77}$ The Bamberg casket has traditionally been known as "Kunigunde's box," associated with Kunigunde, the daughter of Knut (Canute) the Great of Denmark, Norway, and England, who married the future Emperor Henry III in $1036 .{ }^{78}$ We have no such specific details pertaining to the León piece, but it may also have been a rich dowry item — with diplomatic contacts—reflecting a marriage between a Scandinavian woman and an Iberian ruler or aristocrat. I have previously discussed early medieval long-distance marriages for earlier periods. ${ }^{79}$ For example, the sixth-century writer Gregory of Tours (ca. 538-594) in his History of the Franks discussed how Rigunth, daughter of the Frankish King Chilperic, was to be given in marriage to a Visigothic prince in Spain. ${ }^{80}$ Paul the Deacon (ca. 720-799) reported that the sixth-century Lombard King Waccho (r. 510-540) strengthened his position through a series of strategic marriage alliances: "His first wife was a Thuringian princess, subsequently dropped in favour of his second wife, daughter of the Gepid king, who bore

76 Franco Valle, "Viking Art in the Church," 38.

77 Adam of Bremen, History of the Archbishops of Hamburg-Bremen, trans. Francis J. Tschan, intro. Timothy Reuter, Records of Western Civilization, 53 (New York: Columbia University Press, 2002), 67; Roesdahl, "Viking Art in European Churches," 152.

78 Roesdahl, "Viking Art in European Churches," 153.

79 Nancy L. Wicker, "Scandinavian Migration Period Bracteates Found Outside the Nordic Area: Import or Imitation?" in Import and Imitation in Archaeology, ed. Peter F. Biehl and Yuri Y. Rassamakin. Schriften des Zentrums für Archäologie und Kulturgeschichte des Schwarzmeerraumes, 11 (Langenweißbach, Germany: Beier \& Beran, 2008), 243-252, esp. 246.

8o Gregory, The History of the Franks, trans. Lewis Thorpe (New York: Penguin Books, 1974), 6.45. 
him two daughters, who in time were married off to Frankish kings, while his third spouse was daughter of the subjugated Herul king." ${ }^{11}$ European royalty continued to undertake such matrimonial schemes for centuries. A later example is the thirteenth-century "Norwegian-Castilian alliance" discussed by Bruce Gelsinger and Ángel Gordo Molina, when Kristina, the only daughter of King Håkon IV of Norway, married Felipe, a brother of King Alfonso X of Castile in 1258.82 The military and diplomatic expediency of such a partnership may have overshadowed the mundane aspects of the goods exchanged to cement this relationship, but we can imagine that the Norwegian woman Kristina brought exotic Scandinavian items with her, some 150 years after the late Viking Age. Similarly, the León box could have been given to a Nordic woman who was matched with an elite man in northern Iberia at any time after the end of the tenth or early eleventh century, when the Mammen style was the mode. What did the box contain? It could have held a material of sentimental significance to a northerner, or upon its arrival in Spain it could have been filled with a substance characteristic of the region that was new to her.

\subsection{The Container and Its Contents}

Franco Valle notes that the León box itself must have been an exotic treasure in northern Spain, comparable in its strangeness to Islamic caskets known there. ${ }^{83}$ If its contents were also exclusive, it would be even more prized. The box and its contents were not necessarily connected - the cylinder, perhaps made in a Scandinavian workshop (anywhere in the Viking diaspora from the British Isles to Russia) — could have later been packed with a luxurious substance such as ambergris, musk, or camphor after it reached Iberia. ${ }^{84}$ Eventually the precious relics of a saint may have been placed in the box when it was reworked with the current lid — which looks rather different from the openwork bottom plate with its interlaced Viking animal style — and nailed into place to sit in the treasury of San Isidoro for many decades..$^{85}$

81 Paul the Deacon, History of the Lombards, trans. William Dudley Foulke, ed. Edward Peters (Philadelphia: University of Pennsylvania Press, 1974 [first ed. 1907]), 1.21.

82 Bruce Gelsinger, "A Thirteenth-Century Norwegian-Castilian Alliance," Medievalia et humanistica 10 (1981): 55-80; and Ángel Gordo Molina, "La princesa Kristina de Noruega en la corte del rey Alfonso X de Castilla y León. La persecución de objetivos políticos e ideológicos por la vía de las alianzas matrimoniales," Intus-Legere Historia 1/1-2 (2007): 175-19o.

83 Franco Valle, "Viking Art in the Church," 40.

84 Jerrilynn D. Dodds, Al-Andalus, The Art of Islamic Spain (New York: Metropolitan Museum of Art, 1992), 42-43.

85 Christys, Vikings in the South, 7. 
I have discussed the possible functions of carved antler, bone, and walrus ivory objects that resemble the León box in some respect, including jewelry and reliquary caskets, pyxides for the host, needle-cases, knife handles, and salt vessels. However, the León piece differs in a significant respect from other Viking objects because of its openwork technique. How did the openings in the container affect its use? The holes through the wall, lid, and base are too small to allow successful visual inspection of the contents, as might be desired for relics, yet the voids are large enough that it could not hold salt or other herbs unless the contents were wrapped in cloth (most likely silk, a precious, luxurious material) and then packed inside the box. In a discussion of early Islamic precious containers, Lawrence Nees reminds us to consider their contents; he also cites Anthony Cutler's assertion that "pyxides were not designed with specific functions in mind but were for the most part versatile receptacles." ${ }^{86}$ However, the León object could have been commissioned for a specific, pre-determined use that would exploit the exposure of the contents through the openwork antler and metal parts. ${ }^{87} \mathrm{~A}$ key feature of this small box is that whatever was contained inside it was supposed to be encountered with at least one of the senses - if not sight, then perhaps smell.

Martin and Morales Romero both suggest that the box could have held a solid perfume, for instance, myrrh, whose scent would waft through the perforations, especially as the ingredient could be heated slightly as the small cylinder was held in the hand. ${ }^{88}$ This suggestion is consistent with Islamic exotica, but perfume was not a typical Viking commodity, especially if we depend upon Ibn Fadlan's accounts of how filthy Vikings were. ${ }^{89}$ Why would a Scandinavian container be used for such a purpose, and how did it get to Spain? The box may signify a hybrid entity produced by someone who appreciated an Iberian interest in exotic sensuous substances yet was also knowledgeable about Viking styles, negotiating processes of multicultural adjustments in a

86 Lawrence Nees, "What's in the Box? Remarks on Some Early Medieval and Early Islamic Precious Containers," Notes in the History of Art 33 (2014): 67-77, esp. 67.

87 Dodds, Al-Andalus, 43, mentions that some exotic substances were presented in filigree gold nets.

88 Therese Martin, "Caskets of Silver and Ivory from Diverse Parts of the World: Strategic Collecting for an Iberian Treasury," in The Medieval Iberian Treasury in the Context of Cultural Interchange, ed. T. Martin, special issue, Medieval Encounters 25/1-2 (2019): 1-38, esp. 6; and Morales Romero, "Arte Vikingo," 124.

89 Ahmad ibn Fadlan, Mission to the Volga, ed. and trans. James E. Montgomery, in Two Arabic Travel Books, ed. and trans. Tim Mackintosh-Smith and James E. Montgomery (New York: New York University Press, 2014), 76. 
"creolized" environment, as discussed by Jane Webster. ${ }^{90}$ It might have been commissioned by someone who comprehended an intended use of the object in a warm climate. From the ninth through the twelfth centuries, Vikings attacked the coast of Iberia, engaging with Muslim forces in Seville and other locations, ${ }^{91}$ where they could have encountered Andalusi ivory pyxides as containers for highly valued scented substances. ${ }^{92}$ Even though the ingredients were unfamiliar in the North, the type of object could have been known to Scandinavians who returned home after years of raiding al-Andalus. The material of red deer antler could have been obtained anywhere from North Africa to southern Scandinavia, and a traveling Viking craftsman might have been commissioned to make something special for a young princess being sent to marry - and thus cement diplomatic ties—in southern lands where ways of life would be foreign to her.

\section{9}

\section{Conclusion}

The Mammen-style pierced box in León is Scandinavian in style, similar in certain ways to other examples of Viking art, but it is a hybrid piece that does not match the function of any known Scandinavian item of this period. Instead it reflects a fusion of various cultural references. Even today, it is an object that is read differently by those who understand Viking art and recognize the projecting bird's head versus by those who do not perceive the representation of a bird. Details of the artifact's biography are unknown, but threads of its life can be woven together to tell a story that hypothetically can inform us about patronage, diplomacy, cultural exchange, and women's roles across long-distance contacts.

\section{Acknowledgments}

I am very grateful to Therese Martin and Raquel Jaén Gonzalez for making it possible for me to visit San Isidoro and view the León cylinder. I also thank Therese for her comments on an early version of my paper, for giving me useful

$90 \quad$ Jane Webster, "Creolizing the Roman Provinces," American Journal of Archaeology 105/2 (2001): 209-225.

91 Jesús Riosalido, "Los Vikingos en al-Andalus," Al-Andalus Magreb: Estudios Árabes e Islámicos 5 (1997): 335-344.

92 Dodds, Al-Andalus, 43. 
references, for providing practical assistance to come to León, and for kindly providing her photographs of the object. This work was partially supported by The Medieval Treasury across Frontiers and Generations: The Kingdom of LeónCastilla in the Context of Muslim-Christian Interchange, c. 1050-1200 (National Excellence in Research Grant, Spanish Ministry of Economy and Competitivity, HAR2015-68614-P, 2016-2018, PI Therese Martin). Republication in the present volume was supported by the College of Liberal Arts of The University of Mississippi, the Index of Medieval Art (Princeton University), and The Medieval Iberian Treasury in Context: Collections, Connections, and Representations on the Peninsula and Beyond (National Research Challenge Grant, Spanish Ministry of Science, Innovation, and Universities, AEI/FEDER, RTI2018-o98615-BIoo, 2019-2022, PI Therese Martin). 